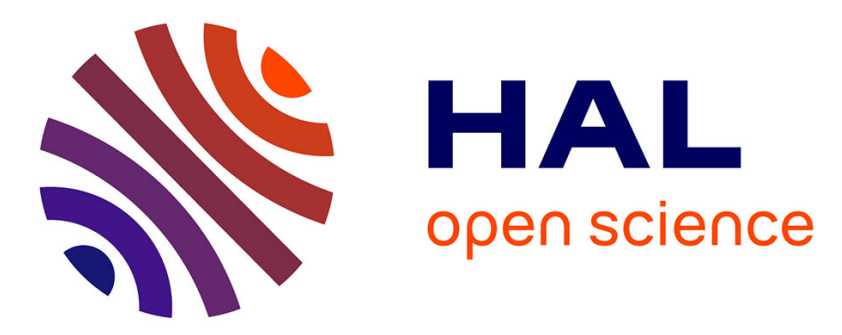

\title{
The Link between the Current International Monetary Non-System, Financialization and the Washington Consensus
}

\author{
Luis Antonio Reyes Ortiz
}

\section{To cite this version:}

Luis Antonio Reyes Ortiz. The Link between the Current International Monetary Non-System, Financialization and the Washington Consensus. Research in International Business and Finance, 2017, 42, pp.429-441. 10.1016/j.ribaf.2015.11.015 . halshs-01895218

\section{HAL Id: halshs-01895218 \\ https://shs.hal.science/halshs-01895218}

Submitted on 14 Oct 2018

HAL is a multi-disciplinary open access archive for the deposit and dissemination of scientific research documents, whether they are published or not. The documents may come from teaching and research institutions in France or abroad, or from public or private research centers.
L'archive ouverte pluridisciplinaire HAL, est destinée au dépôt et à la diffusion de documents scientifiques de niveau recherche, publiés ou non, émanant des établissements d'enseignement et de recherche français ou étrangers, des laboratoires publics ou privés. 


\title{
The Link between the Current International Monetary Non-System, Financialization and the Washington Consensus
}

\author{
Luis Reyes*
}

October 14, 2018

Published in Research in International Business and Finance in 2017.

\begin{abstract}
The main purpose of the present work is to build a bridge between three concepts: the current international monetary system, financialization and the Washington Consensus. Under this approach, the current international monetary non-system (that replaced the Bretton Woods system) imposed by Nixon in 1971 led to the oil shocks that in turn intensified the inflationary pressures of the rest of the decade. The bold resolution to end inflation in 1979 via high interest rates brought about a process of financialization that was cause and consequence of trade and financial liberalization. Interest rates eventually went back to levels comparable to those prevailing before the Volcker shock, which brought about a decline in firms' demand for credit that obliged banks to seek for other clients, i.e. the rest of the world and households. The ideas embedded in the Washington Consensus contributed to the development of this financialization/liberalization process, and these gained strength as the previous regime (characterized by low unemployment rates and high inflation) was being replaced by the current regime paradoxically called the 'Great Moderation'. The process of financialization can be explained by the analysis of the capital structure of U.S. firms.
\end{abstract}

${ }^{*}$ Centre d'Économie Paris Nord, Paris 13. Contact: luisantonio.reyesortiz@univ-paris13.fr and Luis.Reyes-Ortiz@kedgebs.com. Website: www.luisreyesortiz.org. I wish to thank Emmanuelle Moesch for her comments and insights. 
Keywords: Financial Markets and the Macroeconomy (E44); Policy Objectives (E61); International Monetary Arrangements and Institutions (F33); Foreign Exchange (F31).

\section{Introduction}

The current international monetary regime of flexible exchange rates is flawed. National and international economic authorities tend to promote competitiveness, price stability as well as trade and financial liberalization, whereas these measures (when carried too far, as is nowadays the case) enhance inequality, unemployment and financial instability.

Clearly, this statement must not be interpreted in the reverse causal sense that economies should pursue an agenda aimed at being uncompetitive, promote excessive inflation and extreme protectionism. Instead, it should be seen in retrospect, thus as a reflection that over the past four decades economic authorities have focused on (paraphrasing Stiglitz [2008], p. 42) "too narrow a set of objectives, and on too limited a set of instruments" in order to undo the harm caused by previous mistakes; i.e. the Bretton Woods system.

In order to boost competitiveness, the IMF recommends wage moderation to developed and developing economies ${ }^{1}$ as the preferred recipe for these to grow and develop. These recommended measures usually come along with the promotion of productivity-enhancing industries that often make use of capital-intensive techniques, which in turn allows firms to remain in an unskilled-labor-saving production scheme.

Price stability is often perceived as an end, but it is rather a means of achieving competitiveness while at the same time guaranteeing that wealth will not be "inflated" away in the future ${ }^{2}$.

\footnotetext{
${ }^{1}$ For instance the World Economic Outlook published by the IMF [2014] (p. 60) mentions that, in Japan "policy measures could prove less effective at boosting growth than envisaged if they fail to raise inflation expectations, nominal wages, exports, and private investment". Also, when discussing the case of Belarus (p. 65) it states that "[a]lthough financial support from Russia could provide Belarus with some short-term breathing space, steps to reduce wage and credit growth and to increase exchange rate flexibility should be taken expeditiously to narrow imbalances".

${ }^{2}$ For an interesting account of the psychological factors of why people dislike inflation, see Shiller [1996].
} 
Trade and financial liberalization are also key factors in this strategy, for they can be seen as natural extensions of the "no barriers to entry" axiom that is explained in the very first chapters of microeconomics textbooks. Of course, with no tollbooths along the way capital may circulate across borders with no bound, thus making it easier for the world economy to approach its desired state of perfection, or so the story goes.

These policy objectives (competitiveness, price stability and liberalization) are at the core of what is called the Washington Consensus, a development strategy proposed by John Williamson in 1989 that aimed at examining "the extent to which the old ideas of development economics that had governed Latin American economic policy since the 1950s were being swept aside by the set of ideas that had long been accepted as appropriate within the OECD" (Williamson [2009], p. 7). The main thrust of the present article is that, by pursuing these ideals, national and international economic authorities have done more harm than good.

This can be explained in the following way. Since the end of WWII there have been a number of major changes in the international monetary system that can be seen as a non-fortuitous sequence of events. Thats is, with the adoption of the White Plan (instead of the alternative Keynes Plan) after the war, the Bretton Woods system (19451971) proved unable to provide the stability the international financial system required. As a consequence, the Nixon administration suspended the gold-dollar convertibility, thus unilaterally ending the limping gold standard ${ }^{3}$ better known as Bretton Woods system, which in turn intensified the inflationary pressures of the seventies. With the devaluation of the dollar (caused by the collapse of BW), OPEC member countries retaliated with oil price hikes and embargoes that pushed consumer and investment prices up.

In the words of Graetz [2011] (p. 18) "[o]il producing nations lost purchasing power throughout the world as the value of the dollar fell because their oil prices

\footnotetext{
3 "If (...) convertibility is restricted, for example to the requests from central banks, we are in the presence of a limping gold exchange standard, in which case the automatic mechanisms governing the gold standard no longer operate, and the concept itself of convertibility has to be redefined: now convertibility simply means that private agents have the right to freely exchange the various currencies between each other at fixed rates" (Gandolfo [2002] p. 32, emphasis in the original).
} 
were set in dollars. In September 1971, a month after Nixon's speech, at an OPEC meeting in Beirut, its member states increased oil prices by nearly 9 percent explicitly to compensate for the devaluation of the U.S. currency. And the value of the dollar continued to decline for several more years. By mid-1973, the dollar price of gold had risen to more than $\$ 90$ an ounce; by the end of the decade, it exceeded $\$ 450 "$.

As a policy response to this, in 1979 interest rates went up sharply (the Volcker shock), thus ending the inflation problems created by the oil shocks. Since that year several changes took place that, among others, led to the set of policies that are embedded today in the Washington Consensus.

The paper is organized as follows. The following section deals with the Bretton Woods institutions, and how their roles have changed over time, and how these relate to the current international monetary non-system that replaced the Bretton Woods system of fixed (or semi-fixed) exchange rates. Section 3 links the current monetary system to the process of financialization, focusing on the United States economy. Section 4 relates this process to the set of policy prescriptions made in the Washington Consensus. Section 5 concludes.

\section{Bretton Woods Institutions During and After Bretton Woods}

Following the end of WWII, the set of rules in the international financial system agreed upon at the Bretton Woods conference involved the creation of two international organizations: the International Monetary Fund and the World Bank (originally called International Bank of Reconstruction and Development). However, their roles and ideology have greatly changed over time.

During the Bretton Woods years, the IMF guaranteed that the exchange rates of member countries remained tied to the dollar (the key currency, in turn tied to gold) within respectable limits. In contrast, today it allows central banks to accumulate dollars in order to safeguard the value of their currency under the exchange rate regime 
of their choice ${ }^{4}$. Up until the mid-sixties, the World Bank financed reconstruction of devastated (mainly developed) countries involved in the war, whereas today it mainly finances development in low- and middle-income economies.

The fixed exchange rate regime under which these two organizations were created was closely associated with strong counter-cyclical fiscal policies that allowed governments to grow in size, while at the same time employment creation was favored over price stability ${ }^{5}$. In contrast, the current Non-System (a term coined by Williamson [1976]) is associated with price stability (achieved via tight monetary policy), small government and high unemployment rates.

Despite the collapse of the BW system its institutions have not disappeared. Instead they have changed their roles and their ideology, and (since the late seventies) have been pushing for a different policy agenda that has culminated in the current financialized world regime and the Washington Consensus.

\subsection{International Institutions and their Paradoxical Relation with Democracy}

Voting power within the IMF is based on the "relative positions of its member countries in the global economy" ${ }^{\prime 6}$, and not on a one-country-one-vote basis. As a consequence, stricto sensu, decision-making within the Fund is not carried out in a democratic way. Furthermore, one of the Fund's main activities is lending to member countries in times of need, but this is most of the time done conditionally upon reforms ${ }^{7}$, although the latter may even threaten democracy in borrower countries (Brown [2009]). Ironically, the set of recommendations made by this organization often includes "promotion of

\footnotetext{
${ }^{4}$ The fact that the dollar was the key currency during the BW years and that there was a single issuer of this currency that can live beyond its means (the U.S.), and that this is again the case in the present, has led some to define the current international monetary and financial system as Bretton Woods reborn. For a discussion of why this is misleading see Eichengreen [2004].

${ }^{5}$ The literature on the subject is vast, but we refer the reader to two main works that are cited by the Federal Reserve: Santoni [1986] and Steelman [2011].

${ }^{6}$ See the following link: http://www.imf.org/external/about/govstruct.htm

${ }^{7}$ Of course, these reforms are strongly recommended (or rather imposed) on borrowing countries so that their implementation serves as substitute of 'collateral' for the Fund in order to ensure repayment. Naturally, the logic behind conditionality is that the diagnostic and policy advice are the right ones.
} 
democracy" via measures that they see as improving the quality of institutions.

As for the World Bank "[ $t$ ]he quota assigned by the Fund is used to determine the number of shares allotted to each new member country of the Bank" ${ }^{8}$. A somehow differently weighted system of voting than that of the Fund is at work in the WB, and similar policy recommendations are encouraged in the latter although its main focus today is on poverty reduction, with particular emphasis on less developed economies. Currently the Bank provides "low-interest loans, zero to low-interest credits, and grants to developing countries" 9 .

As mentioned above, the Bretton Woods institutions are nondemocratic organizations that see democracy, if only in principle, as a prerequisite for development and growth. Yet they are responsible for the functioning of the international monetary system that governs us all.

Another important item that is commonly present in the list of recommendations of these two institutions (notably the Fund) is fiscal discipline, which in turn implies that governments in developing economies (those which are more in need of funding for development purposes) cannot run large debts, even if large debts are what it takes for the country to be able to develop. Other requirements are "honest governments, an impartial legal system, properly trained and remunerated public officials, transparent regulatory systems, and so on" (Naím [2000], p. 96), which are no doubt laudable characteristics. However, what this strict list seems to ignore is that "any country capable of meeting such stringent requirements is already a developed country" (ibid).

The IMF and the WB operate in conjunction with the economic authorities of member countries, that is, with governments and central banks. The former are oftentimes made up of elected officials, whereas most of the latter are independent of any political influence. This does not mean central banks may not favor a particular political stance, it simply means that their policy is carried out without the approval of any political body or the government, presumably in order to avoid that political parties in power seek reelection by increasing deficit spending financed by the funds

\footnotetext{
${ }^{8}$ See http://www.worldbank.org/en/about/leadership/directors

${ }^{9}$ See http://www.worldbank.org/en/about/what-we-do
} 
provided by central banks. Now, regardless of the good intentions sought by the latter, if they detach themselves from any elected political body they can hardly be seen as democratic institutions ${ }^{10}$.

Nonetheless, an important voice is of the belief that "[i]n a democratic society (...) the ultimate purpose of the central bank is to promote the public good by pursuing a course of monetary policy that fosters economic prosperity and social welfare. In (...) virtually every (...) country, the central bank has a more specific set of objectives that have been established by the government" (Mishkin [2007]). This quotation seems to suggest that because governments set the objectives that central banks execute, the latter are doing so in a way consistent with the will of elected officials, and thus of voters. Nonetheless, if neither governments nor central banks are able to promote democracy democratically, it is just as if they simply meant do as I say not as I do.

Now, the debate about the role of institutions in shaping the economy has been going on since at least the early twentieth century with, for example, the works of Thorstein Veblen. Thus, the argument whereby the quality of institutions represents a key ingredient in bringing about economic well-being was present throughout the Bretton Woods period, and the arguments in favor of better institutions has not ceased to accumulate. However, with the advent of the Washington Consensus the insistence on democracy and institutions under the current international monetary Non-System has taken a different turn, which now aims at economic stability via price stability ${ }^{11}$ as a precondition of development and growth (see Williamson [1993]), rather than maximum employment as a precondition for prosperity.

\footnotetext{
${ }^{10}$ This idea is contested by Dornbusch and Edwards [1989], where the authors argue that "populist macroeconomics" inevitably lead to the opposite of what they actually aim for. Their evidence is based on the cases of Chile (1970-1973) and Peru (1985-1988), and they blame the corresponding "populist" governments for the economic troubles that led to hyper-inflation, although without even mentioning the influence of the external sector (i.e. the oil shocks in the seventies) or without even considering the role of portfolio investment from the point of view of lenders during capital flight episodes (thus attaching too much weight on borrowers, as in the Peruvian case).

${ }^{11}$ Taken literally, this is hardly the truth. What has remained stable over the past thirty five years are consumer price indices, whereas the volatility of equity and housing prices increased dramatically. Thus, when economic authorities and the media refer to price stability, it would be preferable that they define which prices in the first place.
} 


\subsection{Monetary Policy, Change in Policy Objectives and some Conse-}

\section{quences}

As mentioned above, central banks and governments are intermediaries between the Bretton Woods institutions (IMF and WB) and citizens of a given member country. Central banks' main commitment nowadays is to guarantee price stability ${ }^{12}$, whereas in the past their main goal was to aid governments in their task of ensuring the maximum level of employment ${ }^{13}$. By way of comparison, the Employment Act of $1946^{14}$ stated that was "to coordinate and utilize all its plans (...) in a manner calculated to foster and promote free competitive enterprise and the general welfare, conditions under which there will be afforded useful employment for those able, willing, and seeking work, and to promote maximum employment, production and purchasing power" (italics added). This Act was later on replaced by the Full Employment and Balanced Growth, or Humphrey-Hawkins, Act of 1978 (see Santoni [1986]).

The Full Employment and Balanced Growth bill of 1976 "was debated for more than two years and, like its forerunner, was stripped of its substantive provisions when President Carter signed it on October 27, 1978" (Santoni [1986] p. 13). The most hotly debated issue at the time was the concern for price stability (difficult to achieve past the first major oil shock) and its persistent negative association with the unemployment rate. Naturally, if guaranteeing maximum employment was the ultimate goal of the Employment Act, a lowering of the unemployment rate may come along with inflationary pressures ${ }^{15}$, but as price stability was also a goal in the bill,

\footnotetext{
${ }^{12}$ This can be clearly seen in the case of the European Union (of which the ECB is the most powerful economic authority), where the Stability and Growth Pact takes stability more seriously than growth. This is so because "[b]y requesting Member States to coordinate their budgetary policies and to avoid excessive deficits, it contributes to achieving macroeconomic stability in the EU and plays a key role in securing low inflation and low interest rates, which are essential contributions for delivering sustainable economic growth and job creation". See the following link https://www.ecb.europa.eu/mopo/eaec/fiscal/html/index.en.html

${ }^{13}$ There is, however, a third mandate that is no longer part of the discussion: to maintain moderate long term interest rates. In the words of former member of the Board of Governors of the Federal Reserve Frederic Mishkin, this can be explained by the fact that "[b]ecause long-term interest rates can remain low only in a stable macroeconomic environment, these goals are often referred to as the dual mandate; that is, the Federal Reserve seeks to promote the two coequal objectives of maximum employment and price stability" Mishkin [2007] (emphasis in the original).

${ }^{14}$ See the following link: http://www.federalreservehistory.org/Events/DetailView/15

${ }^{15}$ This negative association between inflation and unemployment was not always respected, as was
} 
then "[i]n some circumstances, a temporary tradeoff between the two elements of the dual mandate may exist" (Mishkin [2007]). That trade-off is settled today in favor of price stability, and the transition from aiming at maximum employment to the Great Moderation world in which we currently live is far from being fortuitous. The collapse of Bretton Woods and the consequent oil shocks were the main transitional components that can be explained by a sequence of events, explained below, that in turn led to the Volcker shock and the resulting Great Moderation.

One of our main contentions in the present work is that the change in policy objectives of international organizations and national economic authorities can be traced back to the collapse of the BW system which inevitably led to the devaluation of the dollar, that in turn made the trade balance of the U.S. run into deficit ${ }^{16}$. This in turn led oil producing countries to retaliate with oil price hikes and embargoes because the dollar devaluation implied important losses for the governments of these countries. With the bold resolution taken by Paul Volcker in 1979 to end with inflation and achieve the so-desired real sector stability, financial markets became more prone to instability.

Let us now begin our suggested long-run interpretation of the sequence of economic policy changes that took place in the U.S. economy and that had a deep impact in the world economy. We begin by describing the evolution of the U.S. trade balance and real effective exchange rate which, in our view, were the key variables that motivated the closing of the gold window in August 1971.

the case during the period characterized by the persistence of both in the late seventies (stagflation). This is perhaps what led influential policymakers to argue in favor of price stability, given that demand management was provoking inflation while the at the same time the unemployment rate increased instead of falling, as the Phillips curve predicted.

${ }^{16}$ According to former chairman of the Federal Reserve, Arthur Burns, back in the late seventies/early eighties there was a widespread belief in American circles "that many U.S. industries can no longer compete against more efficient Japanese firms. There is worry as well that American producers are being victimized by unfair competition from low-wage producers in developing countries and subsidized products of European and other foreign enterprises. Such explanations of the U.S. foreign trade deficit contain an element of truth, but hardly more than that" (see Burns [1984]). He then goes on to say that "[ $t$ ] he principal causes of America's recent trade deterioration are to be found elsewhere: in the high value of the dollar in foreign exchange markets, in the faster rebound from recession in the United States than in Western Europe or Japan, and in the unavoidable need of debt-ridden developing countries to practice austerity". The author further adds: "[w]ith the virus of protectionist sentiment spreading, the need for economic statesmanship, especially in the United States and Europe, has become urgent" (ibid.). 
As can be seen in Figure 1, from 1964 to 1972 the U.S. trade balance (right scale) was in deficit, and was close to $2 \%$ of GDP in 1972 . However, once the gold window closed (third quarter of 1971) the narrow Real Effective Exchange Rate (left scale) fell sharply, and the trade balance improved considerably, going from the deficit mentioned above to near balance in just a few quarters. The recipe (closing of the gold window) was thus working.

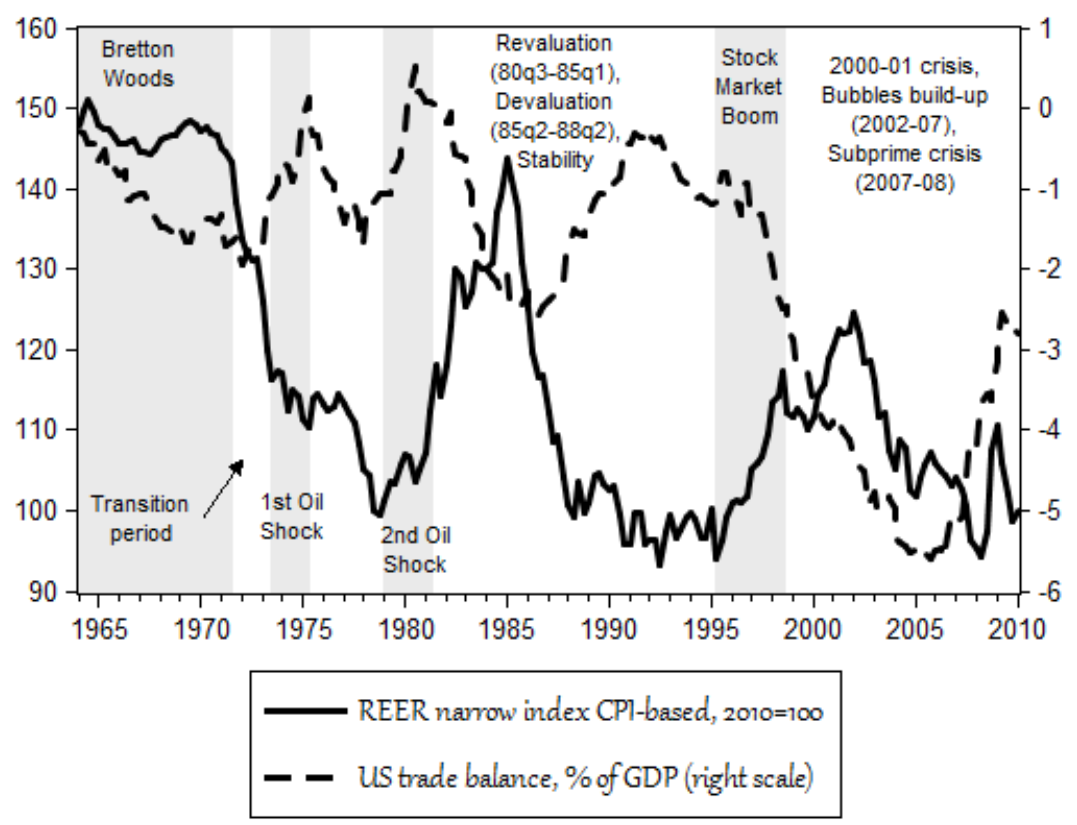

Figure 1: U.S. Real Effective Exchange Rate and U.S. Trade Balance as \% of GDP. Source: BIS (REER) and author's calculations based on data from BEA (trade balance).

From 1973 to 1975 the REER was relatively stable (at least in comparison to its evolution afterwards) but then continued its downward path, until the second oil shock hit the world economy. Between the first and second shocks (the transition period) the trade balance appeared to be insensitive to devaluations, at least in the very short term. The quasi-immediate contractionary policy response from the Fed following the second oil shock in 1979 made the dollar appreciate strongly, and this had the expected negative lagged effect on the trade balance, which started to deteriorate in the third quarter of 1980 .

As a consequence of the sharp increase in interest rates throughout the first half of the 1980s and the corresponding dollar appreciation, the U.S. economy became 
more attractive as a destination for foreign portfolio investment as compared to other economies that were still struggling with inflationary pressures and devaluations (in part caused by the dollar appreciation itself). These capital inflows into the U.S. contributed to the increase in equity prices, which in turn led to the stock market boom and consequent bust in $1987^{17}$. On the other side of the balance sheet of the U.S. capital inflow of the early eighties there was a capital outflow from other economies ${ }^{18}$, which in turn forced them to raise interest rates as well in order to stop the capital drain.

It is in this way that 'western' economies (of which the U.S. is the biggest one) changed their policy agenda from pursuing maximum employment to price stabilization, mainly because good-old expansionary fiscal, monetary and incomes policies would not do the job, at least not without provoking other imbalances. This is so because the world economy relies heavily on the U.S. economy, therefore it is obliged to closely monitor the direction of economic policy in that country (albeit today also in China) so that it can decide on its own economic policy once the main player has made the first move. If, as it was the case in the early eighties, the Fed raises interest rates the dollar appreciates and the U.S. becomes an attractive destination for financial portfolio investors, so that there is a capital inflow in this country. In turn, this makes equity prices rise ${ }^{19}$. Economic authorities outside of the U.S. cannot afford just to wait arms akimbo and see capital flow out of their countries. As a consequence, they are forced to raise interest rates too. Bottom-line: the U.S. economy is (still) too big for other economies to implement policy independently of it.

From 1985 to 1988 the dollar depreciated again with respect to the currencies of its major trading partners. The inverse association between the trade balance and the real effective exchange rate was well respected during this period and up until the end

\footnotetext{
${ }^{17}$ As Minsky [1977] (p. 3-4) put it in his financial fragility hypothesis: "[i]ncoherent behavior occurs when the reaction to a disturbance amplifies rather than dampens the initial disturbance (...). Thus an economy with systemic financial fragility will have a deep depression from time to time".

${ }^{18}$ This naturally includes developing and developed economies. Among the former there were the Latin American economies whose external debt increased dramatically with the dollar appreciation, which ultimately led to the insolvency crisis of 1982. Both developed and developing economies were thus forced to follow deflationary policies since then.

${ }^{19} \mathrm{At}$ the time of writing, this seems to be already underway. See for instance the following online articles: US interest rates Q\&A: what will the Federal Reserve do? (from The Guardian) and Fears grow over US stock market bubble (from the Financial Times).
} 
of the dot-com bubble (1995-1998) in the third quarter of 1998, period after which both series became positively correlated albeit with a lag. During this episode the dollar appreciated again, in part thanks to what Alan Greenspan described as irrational exuberance (see Shiller [2000]).

Another contributing factor that fueled the dollar appreciation and stock market boom beginning in 1995 was the capital repatriation coming from Mexico after the signing of the infamous North American Free Trade Agreement ${ }^{20}$ (NAFTA) with the U.S. and Canada. Clearly, instead of bringing the level of economic activity of Mexico closer to that of its peers, the signing of the agreement just widened the already wide income and wealth gap ${ }^{21}$.

The period 1999-2007 coincides with the build-up and subsequent burst of the housing price bubble (which started around 1995, see Case and Shiller [2003]). Naturally, the fall in the interest rate (see below) played a key role in the expansion of credit demand from households, which then led to the surge in the demand for dwellings and overvaluation in the housing sector. This, coupled with another major stock market bubble made the world financial system collapse when panic spread after Lehman brothers declared bankruptcy in mid-September 2008. Since 1997 and up until 2006, the U.S. trade balance worsened drastically, going from a deficit of 1\% of GDP to close to $6 \%^{22}$ thanks also in part to these developments in the housing sector.

The description of these well-known events aims at providing a sequential interpretation of how the collapse of the BW system led to the oil shocks and strong inflationary pressure, which in turn explain the Fed's reaction to raise interest rates, after which the world economy and financial system changed radically in the way policy was implemented and in the goals it aimed at achieving. Nonetheless, the ideas underlying the shift in policy objectives and implementation are far from being new, and are in

\footnotetext{
${ }^{20}$ For a review of the causes and consequences, from the borrower's perspective, see for instance Dornbusch and Werner [1994] and Palma [2012], respectively.

${ }^{21}$ Even worse, the U.S. economy entered a period of bonanza at the same time that Mexico was hit by the (then) worst financial crisis in its history.

${ }^{22}$ As Bernanke [2005] (p. 2) points out "the U.S. trade balance is the tail of the dog; for the most part, it has been passively determined by foreign and domestic incomes, asset prices, interest rates, and exchange rates, which are themselves the products of more fundamental driving forces". This is also the approach in the present work.
} 
turn embedded in the Washington Consensus ${ }^{23}$.

\section{The Current International Monetary Non-System and}

\section{Financialization}

As we mentioned above, the current international monetary system can be better described as the absence of any particular system. In this context, the institutions that made the BW system be what it was still play a predominant role in the current one. Fixed (or rather semi-fixed) exchange rates played a major role during the BW years. Despite the fact that inflation was far from being a policy objective, it was an unpleasant characteristic of the world economic and financial system back then.

During the BW years chronic inflation was the outcome of several factors, and not exclusively of the welfare state as some were (or are) inclined to believe ${ }^{24}$. Firms set prices according to the evolution of their costs, one of which is labor. Prices of raw materials and profit margins also play a role in determining the prices of goods and services, as Kalecki [1954] pointed out. If there was a problem in the price setting process back in the BW years, it was not the sole responsibility of wage negotiators to pay for the bill, as it actually happened in the early 1980 s.

Regardless of whose responsibility it was, is, should have or must have been, relatively low interest rates and inflation tended to favor debtors while at the same time these two 'euthanized' rentiers (as suggested by Keynes [1936], p. 376). Indeed, low remuneration rates and current contracts for future payments set in currencies that constantly lost value due to price increases is no good deal for bankers, whereas it is a good one for debtors.

Lenders (mainly bankers, also known as rentiers) and their main motivation for

\footnotetext{
${ }^{23}$ The word "consensus" is synonym of unanimous agreement in a given group, and this particular agreement is reached in Washington. Now, the decisions to end the Bretton Woods system in 1971 and raise interest rates in 1979 were far from being made unanimously at an international level. As a consequence, the term Washington Consensus may even be re-interpreted as an oxymoron (as Williamson himself recognized, see Williamson [2004], p. 14) that implies that such consensus may not be a synonym of world-wide consensus, which further undermines democracy.

${ }^{24}$ For instance, Paul Samuelson was of the opinion that "[ $\left.\mathrm{t}\right]$ oday's inflation is chronic. Its roots are deep in the nature of the welfare state" (Samuelson [1986], p. 972)
} 
lending (earning a profit in the form of interest) have not changed much over time. In contrast, borrowers may not increase their demand for credit at the same pace. Moreover, at some point they may not even borrow at all. The list of determinants of the evolution of credit demand may be quite large and may include economic, psychological, anthropological and even ethnic and religious reasons. However, from a purely economic perspective, a key determinant of the demand for credit is the evolution and level of the interest rate. Furthermore, if major lenders (i.e. private banks) perceive that major borrowers (i.e. firms) curtail their demand for credit, then the former may seek for alternative borrowers (i.e. households and the rest of the world).

\subsection{Financialization}

The evolution of the interest rate is closely related to the demand for equities, except under specific conditions ${ }^{25}$. In a given economy, the central bank sets the level of the interest rate, which most of the time is given by the interest rate paid by the treasury (the most trustworthy borrower, at least in theory). In contrast, the price of equities are determined by supply and demand for the corresponding instruments, which are exchanged in stock markets. Debt and equity (or external and internal finance) are alternative sources of funding for investment purposes. In most western liberal economies the bulk of these two are issued by non-financial firms (or simply firms henceforth).

When one of these two instruments becomes more expensive than the other, firms that expect to finance their investment tend to issue the corresponding alternative instrument. Contrary to what the Modigliani and Miller [1958] capital structure irrelevance theorem predicted, this debt-or-equity issuing dilemma has important consequences for the value of the firm. During the seventies and eighties at least three strands of literature emerged from the opposition to M\&M: trade-off theory (attributed to Kraus and Litzenberger [1973]), agency costs (Jensen and Meckling [1976]; Jensen

\footnotetext{
${ }^{25}$ For instance, in the recent past firms issued equties in a much larger proportion than debt, so that any change in the interest rate did not discourage debt issuing anymore. More on this below.
} 
[1986]) and pecking order theory (Myers [1984]; Myers and Majluf [1984]). Other important economists also opposed this irrelevance theorem, among which we can find Hyman Minsky ${ }^{26}$, as well as James Tobin and William Brainard ${ }^{27}$, who based their approach on the writings of J. M. Keynes.

When prices in the real economy finally came under the control of central banks (circa 1979), equity and housing price volatility increased, bringing about financial instability and making financial markets the main drivers of the economy, i.e. the process of financialization. This was achieved thanks to the Volcker shock in 1979. The evolution of the prices of equity and debt may help understand this financialization process.

Figure 2 shows the major financial indicator for the U.S. economy, the S\&P 500 index, divided by the consumer price index (left scale) and the annualized real interest rate (right scale). The period under analysis is the same one used in Figure 1 above. The main purpose of showing these two financial indicators "free of inflation" is to give account of the changes that have taken place in their evolution before and after the Volcker shock, once the evolution of prices (the target variable) are taken out of the picture.

The figure is separated in two sub-periods. The first one goes from 1964 to the first quarter of $1980^{28}$, and is characterized by an "inflationary bias". In the context of the present work, such bias is not defined in the same time-inconsistency sense than in the work of Kydland and Prescott (see the summary given in Dennis [2003]). Instead of giving too much weight to the government and its inflationary stance, we give more weight to the decision of firms to finance their investment. Indeed, when credit is cheap (seen through a fall of the real interest rate) non-financial firms tend to prefer this

\footnotetext{
${ }^{26}$ Minsky's financial instability hypothesis (Minsky [1977] and Minsky [1986]) does not deal directly with the capital structure of firms, although it does address key issues concerning both debt and equity.

${ }^{27}$ Tobin and Brainard [1977] p. 241 mention that "[i]t is true that the celebrated Modigliani-Miller theorem says that a firm's valuation should be independent of its financial structure (...). But there are important reasons for believing that the valuation of a firm's physical assets and their returns cannot be divorced from its financial structure".

${ }^{28}$ Despite the fact that the contractionary monetary policy began in the third quarter of 1979 , its effects were actually felt with a lag of two quarters.
} 


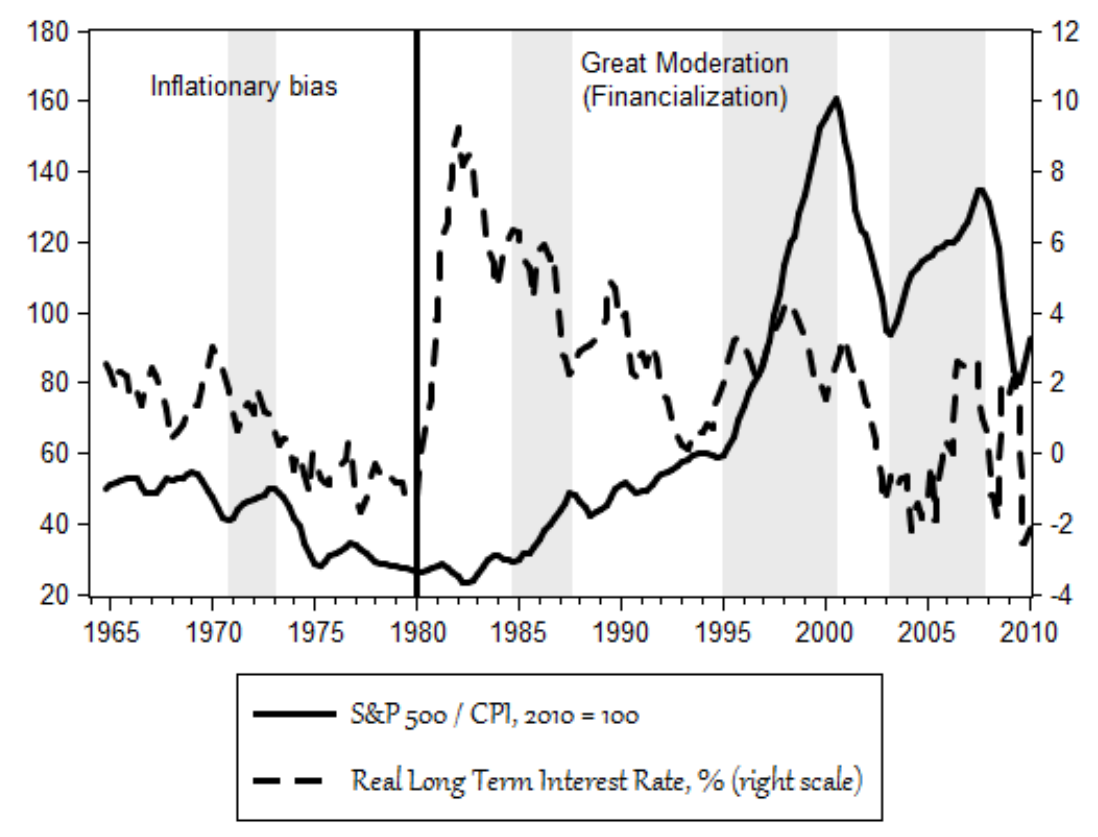

Figure 2: S\&P500 Index/CPI and U.S. Real Long Term Interest Rate. Source: Shiller [2000].

liability over issuing equity, i.e. before $1980^{29}$. Conversely, when credit is expensive firms tend to favor issuing equity instead of debt in order to finance their investment, i.e. after 1980 , the second sub-period characterized by financialization.

Inflationary pressures in 1966 and 1969 as well as the two major oil shocks (1974 and 1979) forced the Fed to raise the nominal interest rate, but this had barely any effect on the real interest rate before 1979. Before the Volcker shock, these interest rate hikes were 'not credible', in the sense implied by Taylor [1993] and the rational expectations school. As a consequence, inflation persisted and the demand for credit by firms actually increased (more on this below). During these episodes increases in equity prices were not enough to catch up with consumer prices, with an important exception (1971-1972).

The shaded areas in the figure represent episodes of rapid increases (and even stronger sudden subsequent drops) in the S\&P 500 index above the increase in consumer

\footnotetext{
${ }^{29}$ The real interest rate provides the rationale for understanding firms' demand for credit in two ways. On the one hand, the nominal interest rate is an indicator of interest disbursements. On the other hand, inflation may be used to measure the expected money value of the amount of credit actually paid in the future. Thus, expectations of the future evolution of inflation play an important role in the decision of firms to issue (or not) debt and in what amount with respect to other instruments.
} 
prices. These are for the periods 1971-1972, 1984-1987, 1995-2000 and 2004-2007. The first of these episodes took place during the period characterized by the inflationary bias in which firms' demand for credit was (on a long term perspective) growing. The remaining three occurred in the second sub-period characterized by what we defined as financialization, and this is far from being a simple coincidence.

It must be noted that in the 1971-1972 episode consumer prices fell, whereas credit demand (or external financing) fell as compared to the demand for own funds (equity issuing). However, after the first oil shock inflation soared and firms increased their demand for credit dramatically. Apart from this small short-lived financial boom, the real interest rate and the price of equity tended to fall from 1964 to 1979 . This is in stark contrast with the period characterized by financialization that began in 1980, when the real interest rate increased in a 'credible' way, which in turn made equity prices grow gradually at first and with a lag (1982-1984) then exponentially. Starting in 1982, the real interest rate began falling. However, it fell thanks to the nominal interest rate and not (as was the case before 1980) due to inflation (CPI-based), which was now under control.

From 1980 to 1982 the real interest rate in the U.S., an approximate measure of the cost of credit in that country, increased sharply from -1.3 to $9.2 \%$. This relatively shortlived but not so innocent move provoked a series of changes in the way finance takes place. As we mentioned above, this caused a strong capital inflow into the U.S. economy and forced other economies to follow the same strategy. It also proved catastrophic for developing economies (namely Latin American) that had an important external debt denominated in dollars, for the strong appreciation of this currency was immediately passed on to these debts (along with the increase in interests due) thus forcing them to declare insolvency in 1982. In order to cope with this imposed external shock, these and other economies were forced to follow the same contractionary measures.

With the capital inflow and the stabilization of consumer prices, U.S. equity prices recovered (starting in 1983) from the downward trend they had followed during the period characterized by high inflation rates. Three major stock market booms are worth 
highlighting: 1984-1987, 1995-2000 and 2003-2007. The first was fueled by the dollar appreciation and the capital inflows received, despite the fact that the real interest rate was falling throughout the boom period. The second was also a consequence of a capital inflow (which, among other sources, came from Mexico) and the increase in the real interest rate, which in turn discouraged firms' from issuing debt. The third was also the result of an increase in the real interest rate and of capital inflows, although the real estate bubble entered the picture this time ${ }^{30}$.

\subsection{Capital Structure}

Other than the stability of consumer prices and near-zero growth rates since the early 1980s, there is hardly anything moderate about the "Great Moderation". To put it in other words, the term moderation is used to describe stability in the real economy, whereas financial markets have become more unstable and fragile than before 1980 . Paradoxically, instability and fragility have spread to the real economy so that the term itself can be seen as an oxymoron that we prefer to replace by the term financialization.

Financialization can be explained thanks to the analysis of the evolution of the capital structure of firms, which is at the core of trade-off theory (Kraus and Litzenberger [1973]) and pecking-order theory (Myers and Majluf [1984]). Trade-off theory is associated with the search of an optimal capital (or financial) structure, meaning that there is an adequate combination of equity and debt issuance that is associated with the investment strategy of a given firm. What is important here is that this body of literature highlights the potential benefits of debt, instead of assuming that the issuance of this instrument is always detrimental for investment.

In contrast, in pure pecking order theory "[i]f external finance is required, firms issue the safest security first. That is, they start with debt, then possibly hybrid securities such as convertible bonds, then perhaps equity as a last resort. In this story,

\footnotetext{
${ }^{30}$ For further details on this point see Bernanke et al. [2011], where the authors argue in favor of the Global Savings Glut hypothesis. While we believe that this hypothesis is quite relevant to explain global movements in capital flows, we are of the opinion that these are caused by movements in interest rates, and not the other way around as the authors suggest. However, we recognize that these two effects may reinforce each other.
} 
there is no well-defined target debt-equity mix, because there are two kinds of equity, internal and external, one at the top of the pecking order and one at the bottom" (Myers [1984], p. 581).

Whether there is an optimal debt-equity ratio (as in trade-off theory) or not (as in pecking order theory) is out of the scope of the present work. What we want to highlight here, however, is that changes in the capital structure of firms are not random nor inconsequential, and these are closely related to changes in interest rates, equity prices, inflation rates and the exchange rate in the aggregate. Figure 3 shows a measure of the capital structure of U.S. firms (debt-equity ratio) and the inflation rate in the same country.

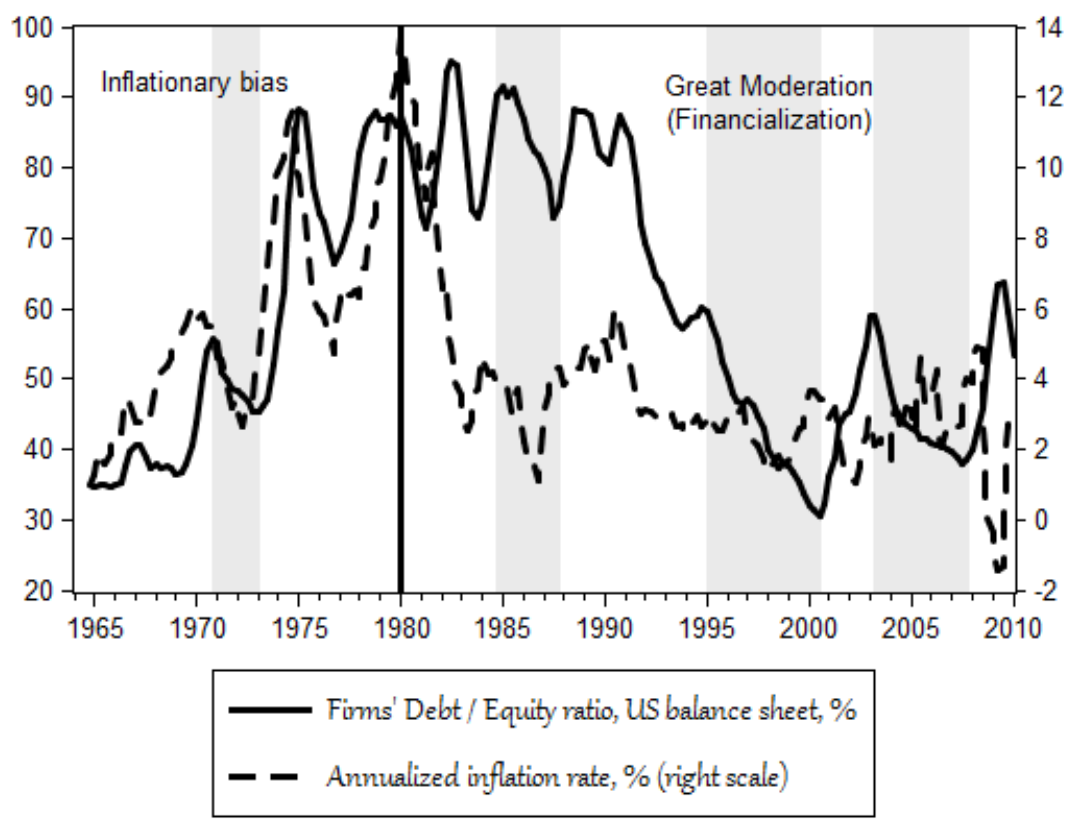

Figure 3: U.S. Non-Financial Corporate Business' Debt/Equity Ratio and Quarterly Inflation Rate. Source: Flow of funds (debt/equity ratio) and BEA (inflation rate).

The period under study in this figure is the same as in the previous ones (19642010), and so is the separation by sub-periods. Likewise, the shaded areas represent spurts in equity prices.

The first striking feature of the figure is the close long-term association of the inflation rate and the debt-equity ratio before 1980 and their clear disconnection begin- 
ning around that year and continues until $2010^{31}$. During this first sub-period firms increased their demand for credit based on the redistributive benefits that inflation brings about for borrowers. Even if timing is not perfect, i.e. thanks to lags, during this period firms' stock of debt tends to increase above (decrease below) their stock of equity when inflation rises (falls) because of the expectation that the money value of the corresponding debt will fall (rise) in the future. Of course, this is the reason why we name our first sub-period "inflationary bias".

A second major characteristic of the figure is the scale of the debt-equity ratio, which is measured in percentages. As can be seen, this ratio does not exceed 100 at any point of the sample under analysis. This indicates that U.S. firms' liabilities consist of equity in a larger proportion than debt in all periods between 1964 and 2010. As a consequence, these have had a strong preference for financing their investment using own funds throughout the whole period.

A third characteristic worth highlighting from the previous graph is that during the first sub-period the real interest rate was low (no more than 3\% except in 1970, see Figure 2), the exchange rate was depreciating (see Figure 1), inflation and the preference for debt were rising. These four developments support the view that U.S. firms had a growing preference for external funding (even if it did not exceed their preference for internal funding) during the period characterized by galloping inflation.

The strong increase in the interest rate at the beginning of the 1980s brought about not only consumer price stability, but also a new financialized regime that began with the strong capital inflow provoked by it. As we saw in Figure 1, from 1980 to 1985 the dollar was appreciating which, together with the increase in the nominal interest rate, attracted foreign capital that in turn fed the banking sector for at least that period. This credit abundance (from the supply side) may explain why, despite the previous increase in the cost of credit, U.S. firms did not reduce their demand for indebtedness. Even if inflation had already fallen, the real interest rate was slowly crawling downward (until 1987), which may explain why firms did not shift their preferences immediately for

\footnotetext{
${ }^{31}$ Data from the Fed's flow of funds is available only up to this year.
} 
equity.

Firms' 'debt aversion' under the new financial regime was more evident since the beginning of the nineties. Interestingly, despite the recession (1990-1991) equity prices did not increase at an unusual speed as it was the case in the intervals 1984-1987, 19952000 and 2003-2007 (the shaded areas in the figure). At the same time the real effective exchange rate remained stable. This begs the question, why did firms rely more on their own funds (instead of external funds) beginning in 1991 despite the fact that there was apparently no incentive to do so? Our explanation is that this was due to the fact that the annualized inflation rate fell from $6 \%$ in the third quarter of 1990 to 3\% in a year later, which again made firms less prone to demand credit. However, what is even more puzzling is that this happened in a period during which the inflation rate and the capital structure of firms were already disconnected. This calls for another possibility, proposed in the next section.

In a nutshell, the inverse U-shaped pattern of the debt-equity ratio (our proxy for capital or financial structure) for the period under analysis can be explained by (1) the evolution of inflation (from 1964 to 1980 and around 1990-1991), (2) continuous as well as sudden increases in the price of equity (shaded areas, notably after 1980), and (3) capital inflows into the U.S. economy, which are in turn capital outflows from other economies, that fueled confidence (and subsequent lack thereof) in stock markets.

\section{The Washington Consensus and Financialization}

The term Washington Consensus "has been used to mean very different things by different people" (Williamson [2009], p. 13). As was mentioned above, this term is used by Williamson to mean a set of ideas that he believed were generally accepted in Washington with respect to what the 'right' prescription for development in Latin America (and, in later versions, the rest of the world) is or should be, in order to help these countries overcome their debt problems ${ }^{32}$ of the 1980s by means of Brady bonds.

\footnotetext{
${ }^{32}$ It is perhaps worth mentioning that such 'debt problems' were largely the outcome of the strong appreciation of the dollar that took place after the Volcker shock and that, naturally, made such debts
} 
By Washington the author means "both the political Washington of Congress and senior members of the administration and the technocratic Washington of the international financial institutions [IMF and WB; LR], the economic agencies of the U.S. government, the Federal Reserve Board, and the think tanks" (Williamson [1990]). To be fair, the author recognizes that "Washington does not, of course, always practice what it preaches to foreigners" (ibid).

The Washington Consensus was a term coined around 1989-1990. It is perhaps just a matter of coincidence that U.S. firms began issuing less debt as compared to equities in order to finance their investment starting the year after. It is all the most tempting to posit that an ideological factor may have played a role in determining the pace at which the debt-equity ratio fell starting in 1990. However, a more credible explanation would be that, beginning in that year, Brady bonds allowed U.S. banks to lend to Latin American countries in a larger proportion than to U.S. firms, thus changing their clientèle instead of their business. With the housing boom in the early 2000s, households also entered the picture.

\subsection{The ten commandments}

The revised version of the 'ten commandments' of the Consensus includes (Williamson [2004], p. 3): (1) small enough budget deficits, (2) efficient allocation of public expenditure (which favors health, education and infrastructure) (3) broadening the tax base, (4) financial liberalization involving an ultimate objective of market determined interest rates, (5) competitive exchange rates, (6) gradual trade liberalization, (7) abolition of barriers impeding the entry of foreign direct investment, (8) privatization of state-owned enterprises, (9) abolition of regulations that impede the entry of new firms

unpayable. Nevertheless, Williamson (just like others before and after him) addresses the issue as if these were borrower problems exclusively. For instance, his 1990 article starts with the following words: "No statement about how to deal with the debt crisis in Latin America would be complete without a call for the debtors to fulfill their part of the proposed bargain by "setting their houses in order," "undertaking policy reforms," or "submitting to strong conditionality". The question posed in this paper is what such phrases mean, and especially what they are generally interpreted as meaning in Washington. Thus the paper aims to set out what would be regarded in Washington as constituting a desirable set of economic policy reforms. An important purpose in doing this is to establish a baseline against which to measure the extent to which various countries have implemented the reforms being urged on them" (Williamson [1990]). 
or restrict competition and (10) the legal system should provide secure property rights without excessive costs and make these available to the informal sector.

In a nutshell, the recommendations "that Washington urges on the rest of the world may be summarized as prudent macroeconomic policies, outward orientation, and free-market capitalism" (Williamson [1990]).

Like the term Washington Consensus itself, prudent macroeconomic policies may also mean different things to different people, but this definition may also vary depending on particular circumstances at different times. As a consequence, we will not focus on this particular point. Nonetheless, it is worth highlighting that Williamson considers that the Washington Consensus does not focus exclusively on price stability, but that it also "requires an attempt to stabilize the real economy à la Keynes" (Williamson [2004], p. 13). Thus, in order to avoid semantic confusion, in the remaining of the paper we will focus on what we are sure the consensus actually aims at, taking into account the 'ten commandments'.

The objectives of outward orientation and the promotion of free-market capitalism are perhaps the most salient features of the Consensus. For these aim at fostering an economic environment that resembles pretty much the perfect world of microeconomics textbooks. The first three commandments are directed towards the first objective of prudent macroeconomic policies, so we will not deal with these. The fourth, fifth, sixth and seventh commandments are directly related to outward orientation, whereas the remaining three are more in line with the promotion of free-market capitalism.

\subsection{Interest Rates, Exchange Rates and Liberalization}

It is doubtful that the strong increase of interest rates in 1979 was the result of the free interplay of market forces. What is clear, however, is that the evolution of interest rates after that period contributed to the capital outflows/inflows briefly described above. The Global Savings Glut hypothesis (Bernanke [2005]) seems to favor the hypothesis whereby (as Bernanke et al. [2011] suggest) U.S. assets are the safest assets, so that the strong demand for these generates capital inflows in this country, thus making the 
interest rate fall.

In contrast, a second alternative would provide more support to the good-old Keynesian covered interest parity story, to which we adhere. The rationale for this alternative is the following. If movements in interest rates come first and if portfolio investment is desired in a given economy, then a central bank with discretionary powers may raise the interest rate above foreign interest rates (risk discounted) in order to attract capital from the latter. If, furthermore, the central bank in question is from one of the most important economic blocks in the world with well-rated financial assets, then this would force other central banks from minor economic blocks to follow the same strategy in order to avoid a major capital drain. Of course, the story may also be told the other way around when there are excessive (potentially undesired) capital inflows.

Naturally, once interest rates begin rising (falling) the capital inflow (outflow) may reinforce the increase (fall) of interest rates, in which case free market forces may have little to do with the determination of the latter because the first move would be imposed by central bankers, not the market.

Now, if inflation is not a problem (as is the case since the "Great Moderation"), then interest rate hikes may only make matters worse for debtors (be it firms, households or governments at home or abroad) given that high nominal interest rates in a noninflationary world means high real interest rates. As a consequence, this pushes equity prices up, which is further reinforced by an overvalued currency and is in turn compatible with interest rate increases. Coincidentally, an overvalued currency makes competing currencies devalue, which in turn enhances these other economies' outward orientation by making them seemingly more competitive (especially so if they guarantee price stability via low wages). Of course, all this may be achieved only if trade and financial liberalization are guaranteed from the start.

Let us now take a little detour to link the previous discussion with the four commandments (4 to 7) related to outward orientation, and these to the collapse of the BW system and the Volcker shock under a long term perspective. 
Following the closing of the gold window, the dollar depreciated and the U.S. trade balance improved, which in turn provoked a capital outflow. Hence, previous undesired excessive inflows were reverted. The capital flight lasted for roughly the whole decade of the seventies (with all its consequences, described in the second section), until the bold decision made by Paul Volcker to raise interest rates in a 'credible' way made the U.S. a desired destination for portfolio and foreign direct investments again. This lasted for the first half of the eighties, during which mainly Latin American capital drains translated into a capital bonanza in the U.S. The dollar depreciated again from 1985 to 1988 , but this was coupled with a stock-market boom and consequent crash (1984-1987) that helped the U.S. in conserving its reputation as a profitable destination.

With the creation of Brady bonds in 1989 Latin American governments and firms were able to borrow in international markets again, so that capital flew again out of the U.S. With the 'Tequila effect' capital flew out of Mexico and other economies and back in the U.S., which in turn contributed to the internet bubble that burst in 2000. Before that, capital had already gone in and out of Russia (1998) and Brazil (1999) and back in the U.S. and other destinations. This last U.S. repatriation was possible thanks to the real effective dollar revaluation that lasted from 2000 to 2002, period after which the real interest rate, the price of equities and housing increased dramatically. Sadly, all this ended leading to the sub-prime crisis that imploded in September 2008.

This begs the question, why have the Washington authorities pushed for freely determined interest rates, exchange rates, as well as trade and financial liberalization? The sequence of events just described may provide a possible source of discussion for a better understanding of why one-sided liberalization was a necessary step for outward orientation outside of the U.S. This explanation may not be incompatible with existing ones.

\subsection{Free-Market Capitalism}

The logic behind the privatization of state-owned enterprises obeys (at least) two seemingly desirable principles: efficiency and small governments. The argument whereby 
private firms are more efficient than governments in making decisions concerning production, distribution and prices has been in the heads of policymakers way before the 1980s. It is, however, with Thatcher and Reagan that these ideas gain force from that decade on. This argument, coupled with the aversion towards intervention and fears of state-driven crowding-out, made privatization all the more desirable because by selling public firms governments would let markets do their job better than themselves, while at the same time public debts will be paid back. This, of course, would also be helpful in limiting the size of governments.

Abolition of regulations that impede the entry of new firms or restrict competition (the ninth commandment) is just a natural extension and ally of trade and financial liberalization $^{33}$. From a purely microeconomic perspective, there may be nothing wrong with letting private firms enter a given market or that these are left to compete with each other in an environment that avoids predatory (i.e. monopolistic) practices. Following this logic, less entry costs (which are ultimately received by the government when they exist) serves the double purpose of promoting competition and limiting the size of the government.

Small governments tend to have less regulatory powers than large ones. Privatization and deregulation (whether prudent or otherwise) are complementary. Protection of property rights (without excessive costs) points in the same direction of allowing the private sector to fulfill its primary role as the ultimate provider of prosperity, clearly because (under this logic) the private sector knows better than the government.

In spite of all the benefits small governments and deregulation may bring about, there are also major drawbacks. One of these is related to the fact that when the public sector loses weight in the economy it also loses power over the latter. As a consequence its goals become more difficult to achieve. If the ultimate goal of the government is (as it seemed to be in the post-war period) to guarantee the maximum level of employment, its capacity to achieve it can be seriously undermined if there is a second objective in the dual mandate and whose policy objectives are different and even contradictory.

\footnotetext{
${ }^{33}$ To be fair, Williamson favors foreign direct investment over portfolio investment. The latter, according to his post-1990 versions of the Consensus, should be regulated.
} 
At the same time that governments were perceived as being too big and were forced to reduce their size (via privatizations, reduction of subsidies and debts, and the like) central banks gained weight as economic authorities. Of course, their main policy objective (price stability) also became a priority and was superposed to that of the government. The strong inflationary pressures of the 1970s (in part caused by the collapse of the BW system) set the basis for this paradigm shift to take place.

The coexistence of rising unemployment and inflation was the perfect signal for the whole process to start, and for price stability to weight more than maximum employment as a policy goal to be pursued. This inevitably led to financialization.

\section{Conclusion}

Competitiveness and price stability are two sides of the same coin (Eichengreen [2004]). These two policy goals are consistent with the current financialized regime whose origin can be traced back to the collapse of the Bretton Woods system and the Volcker shock. One of its main characteristics is the insistence on price stability in the real sector that, paradoxically, is coupled with volatility in equity prices, interest rates and housing prices. Therefore, financial instability and fragility are more frequent since the beginning of the 1980s than between the end of WWII and the late seventies.

As a side effect of these developments, wealth and income inequalities have increased worldwide. Part of the explanation of why this is the case can be found in the fact that the main policy objective of economic authorities changed from maximum employment to price stability.

Non-financial firms are exposed to financial fragility because they are highly dependent on equity rather than on debt. In contrast, households are now more exposed to debt, in part because banks made access to credit easier for them after they realized that firms had increased their preference for equity.

After 1980 stock markets around the globe (mainly led by the New York Stock Exchange) have been subject to more episodes of boom and bust than during the 1945- 
1980 period. This is in part due to the control of consumer prices starting in 1979, year after which firms' demand for credit was disconnected from the evolution of the inflation rate. This forced other countries around the world to pursue the same strategy and policy goals.

The Washington Consensus (a term coined in 1989 by John Williamson) was a set of policy recommendations for Latin American countries that most of (political and technocratic) Washington would agree on back then. This set of policies are nowadays recommended by international organizations, such as the IMF and the World Bank. These institutions were created together with the Bretton Woods system and are still influential, although the latter is long gone since the gold window closed and the fixed (or semi-fixed) exchange rates ceased to exist.

The link between the current international monetary non-system (a term also coined by Williamson), financialization and the Washington Consensus can be seen via the analysis of the capital structure of firms, which has suffered substantial changes since the early seventies. These changes can be explained by the evolution of interest rates, exchange rates and equity prices.

In a nutshell, the adoption of the White Plan led to a system that was later on repudiated due mainly to the fact that such plan (crystallized in the BW system) implied a dollar appreciation and a corresponding loss of competitiveness for the United States (the Triffin Dilemma). With the depreciation caused by the closing of the gold window the oil shocks took place, which in turn led to an intensification of inflation and supply-side troubles that ultimately led to massive unemployment, thus leading to stagflation in the second half of the seventies. The solution to inflationary pressures came with a strong increase in interest rates from the Fed that significantly changed the international financial configuration since then, and further led to a development strategy (closely in line with the events just described) coined as the Washington Consensus. 


\section{References}

B. Bernanke. The global saving glut and the us current account deficit. Speech delivered at the Sandridge Lecture, Virginia Association of Economists, -(-):-, 2005.

B. Bernanke, C. Bertaut, L. Pounder DeMarco, and S. Kamin. International capital flows and the returns to safe assets in the united states, 2003-2007. Board of Governors of the Federal Reserve System. International Finance Discussion Papers, -(1014):-, 2011.

C. Brown. Democracy's friend or foe? the effects of recent imf conditional lending in latin america. International Political Science Review, 30(4):431-457, 2009.

A. Burns. The american trade deficit in perspective. Foreign Affairs, -(-):-, 1984.

K. Case and R. Shiller. Is there a housing bubble in the housing market? Brookings Papers on Economic Activity, -(2):299-362, 2003.

R. Dennis. Time-inconsistent monetary policies: Recent research. FRBSF Econo;ic Letter, $-(10):-, 2003$.

R. Dornbusch and S. Edwards. Macroeconomic populism in latin america. NBER Working Paper Series, -(2986):-, 1989. URL http://www. nber . org/papers/w2986.

R. Dornbusch and A. Werner. Mexico: Stabilization, reform, and no growth. Brookings Papers on Economic Activity, -(1):253-315, 1994.

B. Eichengreen. Global imbalances and the lessons of bretton woods. NBER Working Paper Series, -(-):-, 2004.

G. Gandolfo. International Finance and Open-Economy Macroeconomics. Springer, 2002.

M. Graetz. The End of Energy. The Unmaking of America's Environment, Security, and Independence. MIT Press, 2011.

IMF. World economic outlook. World Economic and Financial Surveys, -(14):-, 2014.

M. Jensen. Agency costs of free cash flow, corporate finance, and takeovers. American Economic Review, 76(2):323-329, 1986.

M. Jensen and W. Meckling. Theory of the firm: Managerial behavior, agency costs and ownership structure. Journal of Financial Economics, 3(4):-, 1976.

M. Kalecki. Theory of Economic Dynamics: An essay on cyclical and long-run changes in the capitalist economy. London, Allen and Unwin, 1954.

J. M. Keynes. The General Theory of Employment, Interest and Money. Great Mind Series, Prometheus Books, reprint, 1936.

A. Kraus and R. Litzenberger. A state preferences model of optimal financial leverage. Journal of Finance, 28(911-922):911-922, 1973.

H. Minsky. A theory of systemic fragility. Paper prepared for the Conference on Financial Crises, NY, -(-):-, 1977. 
H. Minsky. Stabilizing an Unstable Economy. McGraw Hill, 1986.

F. Mishkin. Monetary policy and the dual mandate. Address at Bridgewater College, Bridgewater, VA, -(-):-, 2007.

F. Modigliani and M. Miller. The cost of capital, corporation finance and the theory of investment. American Economic Review, 48(3):261-297, 1958.

S. Myers. The capital structure puzzle. The Journal of Finance, 39(3):575-592, 1984.

S. Myers and N. Majluf. Corporate financing and investment decisions when firms have information that investors do not have. Journal of Financial Economics, -(13):187-221, 1984.

M. Naím. Washington consensus or washington confusion? Foreign Policy, -(-):87-103, 2000.

G. Palma. How the full opening of the capital account to highly liquid financial markets led latin america to two and a half cycles of 'mania, panic and crash'. CWPE, -(1201): $-, 2012$.

P. Samuelson. The Collected Scientific Papers of Paul A. Samuelson, chapter Living with Stagflation, pages -. The MIT Press, 1986.

G. Santoni. The employment act of 1946: Some history notes. Federal Reserve Bank of St. Louis Review, -(68):5-16, 1986.

R. Shiller. Why do people dislike inflation? Cowles Foundation Discussion Paper, -(1115): $-, 1996$.

R. Shiller. Irrational Exuberance. Princeton University Press, 2000.

A. Steelman. The federal reserve's 'dual mandate': The evolution of an idea. Federal Reserve Bank of Richmond Economic Brief, -(11-12):-, 2011.

J. Stiglitz. The Washington Consensus Reconsidered, chapter Is there a Post-Washington Consensus Consensus?, pages 41-56. Oxford University Press, 2008.

J. Taylor. Discretion versus policy rules in practice. Carnegie-Rochester Conference Series on Public Policy, -(39):195-214, 1993.

J. Tobin and W. Brainard. Asset markets and the cost of capital. Cowles Foundation Papers, -(440):-, 1977.

J. Williamson. Reflections on Jamaica, chapter The Benefits and Costs of an International Nonsystem, pages 54-63. Princeton University, 1976.

J. Williamson. Latin American Adjustment: How Much Has Happened?, chapter What Washington Means by Policy Reform, pages -. Peterson Institute for International Economics, 1990.

J. Williamson. Democracy and the "washington consensus". World Development, 8(21): 1329-1336, 1993. 
J. Williamson. The washington consensus as policy prescription for development. "Practitioners of Development", World Bank Lecture, -(-):-, 2004.

J. Williamson. A short history of the washington consensus. Law and Business Review of the Americas, 15(2):-, 2009. 